\title{
Chapter 1 \\ Concerns and Threats of Contamination on Aquatic Ecosystems
}

\author{
Ishrat Bashir, F. A. Lone, Rouf Ahmad Bhat, Shafat A. Mir, Zubair A. Dar, \\ and Shakeel Ahmad Dar
}

\subsection{Introduction}

Anthropogenic activities bring almost contamination and subsequent pollution to our varied ecosystems. "Pollution is defined as the production and or introduction by man, directly or indirectly of substances or energy into the environment, resulting in deleterious effects to living resources, including human beings or interfere with amenities and other uses of the environment (Don-Pedro 1990)." Pollution is one of the prime problems that humans face in the whole world particularly in the developing countries. However, produced by humans and their activities, it has harmful effects on man's environment and resources (Mendil and Uluözlu 2007). The discharge of various pollutants into the aquatic environments is the outcome of countless anthropogenic activities, threatening the health of the living beings and damaging the quality of the environment by rendering water bodies unsuitable (Abowel and Sikoki 2005; Ekubo and Abowel 2011). Aquatic environments are pickers for anthropogenic contamination and industrial wastes and leaks, whether chemicals or solid pollutants (Hampel et al. 2015; Bhat et al. 2017). These wastes can be "heavy metals, detergents, microfibers, plastic or non-plastic origin," etc., and contribute to "aquatic pollution problems" (Hampel et al. 2015). Aquatic environs are addressee for plenty of pollutants and their outrageous toxic actions (Hampel et al. 2015). "Chemicals reaching aquatic ecosystems include radioactive elements" ("strontium, cesium, radon"), metals ("cadmium, mercury, lead"), industrial solvents and "volatile organic compounds" ("tri- and tetrachloroethylene, chlorofluorocarbons, benzene, xylenes, formaldehyde"), "agrochemicals" ("fertilizers and pesticides"), household products ("detergents, cleaners, paints"), "fuel combustion" ("N and sulfur oxides," "polycyclic aromatic hydrocarbons," "carbon monoxide," and "carbon dioxide"), "nanoparticles," personal care products, "microplastics,

I. Bashir $(\triangle)$ F. A. Lone · R. A. Bhat · S. A. Mir · Z. A. Dar · S. A. Dar Sher-e-Kashmir University of Agricultural Sciences and Technology,

Jammu, Jammu and Kashmir, India 
antibiotics," as well as a huge variety of prescription (Hampel et al. 2015)" and "nonprescription drugs and pharmaceuticals of human and veterinary medicine" (Hughes et al. 2013; Larsson 2014; Malaj et al. 2014; Hampel et al. 2015).

"Aquatic ecosystems, particularly the freshwater ecosystems, are exposed to supplementary contamination than other environs, as water is used in various industrial practices as well as release of discharges commencing from industry" and urban growths (Demirak et al. 2006; Fernandesa et al. 2007). "Water pollution is a worldwide task that has augmented in both advanced and emerging nations" (MateoSagasta et al. 2017). "Universally, $80 \%$ of municipal wastewater is discharged into water bodies untreated, and industry is responsible for dumping millions of tons of heavy metals" (Mateo-Sagasta et al. 2017), "solvents, toxic sludge and other wastes into water bodies each year" (WWAP 2017; Mateo-Sagasta et al. 2017). Agriculture, exploits "70\% of water globally and plays a key part in water contamination" (Mateo-Sagasta et al. 2017). Huge amounts of "agrochemicals," "organic matter," "drug residues," "sediments," and "saline drainage" from agricultural lands are released into water bodies (Mateo-Sagasta et al. 2017) and hence poses significant threats to "aquatic environments," "human health," and "productive activities" (UNEP 2016; Mateo-Sagasta et al. 2017). Most aquatic ecosystems have a natural tendency to dilute pollution to some extent, but severe contamination of aquatic ecosystems results in alteration in the fauna and flora of the community (MateoSagasta et al. 2017). The onset of human civilization in itself discloses the history of aquatic pollution (Mateo-Sagasta et al. 2017). Moreover, aquatic pollution did not receive significant consideration until a threshold level was reached with hostile outcomes on the "ecosystems" and "living organisms" including "humans" (Halpern et al. 2008; Mateo-Sagasta et al. 2017). Therefore, "pollution and its effects are considered as one of man's greatest crimes against himself. Pollutants may cause primary damage, with direct identifiable impact on the environment, or secondary damage in the form of minor perturbations in the delicate balance of the biological food web that are detectable only over long time periods" (Sharma 2012; Al Naggar et al. 2014; Ghani 2015). Thus, "maintaining the quality of aquatic ecosystems represents one of the most formidable challenges facing global society in the twentyfirst century" (Hampel et al. 2015).

\subsection{Aquatic Ecosystems}

Aquatic ecosystems are water-based environments in which biotic components interact with abiotic components of the aquatic ecosystem. "Aquatic ecosystems" are usually divided into two types: the "marine ecosystem" and the "freshwater ecosystem" (Barange et al. 2010). Marine ecosystem is the largest water ecosystem which covers over 70\% of the Earth's surface. The marine ecosystem is subdivided into "oceans," "estuaries," "coral reefs," and "coastal ecosystems." Freshwater ecosystems cover less than $1 \%$ of the Earth's surface. The various kinds of freshwater ecosystems are lotic ecosystem, lentic ecosystem, and wetland ecosystem. 


\subsection{Human Activities Resulting in Contamination of Aquatic Ecosystems and Their Adverse Impacts}

Anthropogenic activities such as "deforestation," "filling and construction of canals," "dams," "roads and bridges," "agricultural," and "industrial and domestic activities" result in contamination of aquatic environments. Human settlements, industries, and agriculture are the main sources of water pollution (Table 1.1).

Table 1.1 Sources and route of pollutant discharge into aquatic environs (NEST 1991; MateoSagasta et al. 2017)

\begin{tabular}{|c|c|c|}
\hline Contamination & Source & Route \\
\hline $\begin{array}{l}\text { "Oxygen- } \\
\text { demanding wastes } \\
\text { (organic } \\
\text { pollutants)" }\end{array}$ & $\begin{array}{l}\text { "Domestic sewage, human and animal } \\
\text { wastes (such as wastes from canneries and } \\
\text { wood pulp mills)" }\end{array}$ & $\begin{array}{l}\text { "Thrown, dumped or } \\
\text { released into streams and } \\
\text { rivers or into gutters, drains } \\
\text { from where they may get } \\
\text { washed by run-off into } \\
\text { water bodies" }\end{array}$ \\
\hline $\begin{array}{l}\text { "Infectious disease } \\
\text { agents" }\end{array}$ & $\begin{array}{l}\text { "Domestic sewage, human and animal } \\
\text { wastes" }\end{array}$ & $\begin{array}{l}\text { "Washing, swimming or } \\
\text { working in paddy rice } \\
\text { fields and on irrigated } \\
\text { land" }\end{array}$ \\
\hline $\begin{array}{l}\text { "Plant nutrients } \\
\text { such as nitrate, } \\
\text { phosphate and } \\
\text { others" }\end{array}$ & "Fertilized farm lands, ashes and detergent" & $\begin{array}{l}\text { "Run-off from fertilized } \\
\text { farmlands" }\end{array}$ \\
\hline $\begin{array}{l}\text { "Pesticides } \\
\text { (insecticides and } \\
\text { herbicides)" }\end{array}$ & "Organic and inorganic chemicals" & $\begin{array}{l}\text { "Run-off from pesticides } \\
\text { associated with farmlands" }\end{array}$ \\
\hline $\begin{array}{l}\text { "Industrial effluents } \\
\text { which include DDT, } \\
\text { dyes, mercury, } \\
\text { cadmium" }\end{array}$ & $\begin{array}{l}\text { "Textile factories, distilleries pulp and paper } \\
\text { mills, fertilized plants, chemical and allied } \\
\text { industry, food, beverages and tobacco } \\
\text { industries, soap, detergents and } \\
\text { confectionery industries" }\end{array}$ & "Human discharges" \\
\hline "Eroded sediments" & "Deforestation and accelerated soil erosion" & $\begin{array}{l}\text { "Soil erosion, urban storm } \\
\text { water runoffs and dredging } \\
\text { activities" }\end{array}$ \\
\hline $\begin{array}{l}\text { "Other solid } \\
\text { wastes" }\end{array}$ & "Metals, plastics, artificial fibers etc." & $\begin{array}{l}\text { "Dumping by human } \\
\text { beings due to poor } \\
\text { management of waste } \\
\text { disposal" }\end{array}$ \\
\hline $\begin{array}{l}\text { "Petroleum } \\
\text { products" }\end{array}$ & $\begin{array}{l}\text { "Drill cuttings," "drilling mud (fluids used to } \\
\text { stimulate the production processes)," } \\
\text { accidental discharges of "crude petroleum," } \\
\text { "refinery effluents" which include "oill" and } \\
\text { "grease," "phenol," "cyanide," "sulphide," } \\
\text { "suspended solids," "chromium," and } \\
\text { "biologically oxygen demanding organic } \\
\text { matter" }\end{array}$ & $\begin{array}{l}\text { "Petroleum, exploration, } \\
\text { exploitation, refining, } \\
\text { transportation, storage, } \\
\text { marketing, use and } \\
\text { ruptured oil pipelines" }\end{array}$ \\
\hline
\end{tabular}


In most developed nations, agriculture is the major factor in the degradation of water ecosystems. In the "European Union, 38\% of water ecosystems are significantly under agricultural pressure" (WWAP 2015; Mateo-Sagasta et al. 2017). In the USA, "agriculture is the leading source of pollution in rivers and streams" (Mateo-Sagasta et al. 2017), the second main source in wetlands, and the third main source in lakes (USEPA 2016; Mateo-Sagasta et al. 2017). In China, "agriculture is accountable for a huge portion of surface-water pollution and is responsible almost entirely for groundwater pollution" (Mateo-Sagasta et al. 2017) by nitrogen (FAO 2013; Mateo-Sagasta et al. 2017). In emerging nations, the unlimited amounts of raw municipal and industrial wastewater are major threats (Mateo-Sagasta et al. 2017).

\subsubsection{Agrochemicals}

The ever-increasing "demand for food has led to the land clearance and the expansion of agriculture" which have "contributed to the higher pollution loads in the water" (Mateo-Sagasta et al. 2017). Increase in the population growth has increased the food demand, which has resulted in the increase in the quantity of agrochemicals used to increase the production (Schwarzenbach et al. 2010). The "unsustainable use of agrochemicals" ("fertilizers, pesticides, herbicides and plant hormones") to rise the production has resulted in "greater pollution masses" in the environment, including "rivers," "lakes," "aquifers," and "coastal waters" (Mateo-Sagasta et al. 2017; Bhat et al. 2018; Mushtaq et al. 2018). More importantly, "agricultural areas gather an extensive variety of agrochemicals from nearby fields" due to "run off," "direct drift," and "leaching," and these areas are "the principal receivers of agrochemicals" (Rathore and Nollet 2016).

\subsubsection{Nutrients}

When "fertilizers are applied at a higher rate than they are fixed by the soil, or taken up by the crops or when they are taken off through surface runoff from the soil surface leads to water pollution." "Excess nitrogenous fertilizers and phosphate fertilizers can leach into groundwater or reach into surface water bodies through surface runoff" (Mateo-Sagasta et al. 2017). If "organic manure" is applied "in excess in the agricultural fields," it will lead to "diffuse water pollution." Mostly, "manure is not stored in confined areas and during heavy rainfall events it can be washed into waterways via surface runoff." The "high-nutrient concentration together with other substances results in the nutrient enrichment eutrophication" of "lakes," "reservoirs," "ponds," and "coastal waters," which leads to excessive growth of aquatic plants_-"algae blooms" that destroy other aquatic plants and animals. "About 415 coastal areas have been identified worldwide which experience eutrophication" (Mateo-Sagasta et al. 2017), of which 169 are hypoxic (WRI 2008; Mateo-Sagasta 
et al. 2017). The "excessive buildup of nutrients may also increase the adverse health effects" (Mateo-Sagasta et al. 2017), such as "blue-baby syndrome- due to high levels of nitrate in drinking water" (Mateo-Sagasta et al. 2017). "Nitrate from agriculture leaches into the groundwater is the most common chemical contaminant in the world's groundwater aquifers" (Mateo-Sagasta et al. 2017).

\subsubsection{Pesticides}

Pesticides such as "insecticides," "herbicides, and fungicides" are applied extensively in agriculture fields in several nations (Schreinemachers and Tipraqsa 2012; Mateo-Sagasta et al. 2017; Bhat et al. 2018) and get washed into aquatic ecosystems and pollute the water resources (Mateo-Sagasta et al. 2017). They contain "carcinogens and other poisonous substances that may kill aquatic life" or may be absorbed by them (Mateo-Sagasta et al. 2017) and pass through the "food chain until they become toxic to humans" (Mateo-Sagasta et al. 2017). "Millions of tons of pesticides are used in agriculture fields" (FAO 2016a; Mateo-Sagasta et al. 2017). "Acute pesticide poisoning causes significant human morbidity" (Mateo-Sagasta et al. 2017) and "mortality worldwide, especially in low income countries, where poor farmers often use highly hazardous pesticides" (Mateo-Sagasta et al. 2017).

\subsubsection{Salts}

Through irrigation, accumulated salts in soils are transported into receiving water bodies by drainage water and cause salinization (Mateo-Sagasta et al. 2017). The "intrusion of saline seawater into groundwater aquifers as a result of excessive groundwater extractions for agriculture is another important cause of salinization in coastal areas" (Mateo-Sagasta and Burke 2010; Mateo-Sagasta et al. 2017). "Major water-salinity problems have been reported in Argentina, Australia, China, India, the Sudan, the United States of America, and many countries in Central Asia" (FAO 2011). "Highly saline waters alter the geochemical cycles of major elements such as carbon, iron, nitrogen, phosphorus, silicon and sulphur" (Herbert et al. 2015; MateoSagasta et al. 2017) with overall impacts on ecosystems (Mateo-Sagasta et al. 2017). Salinization can affect freshwater biota (Mateo-Sagasta et al. 2017) by "causing changes within species and community composition" (Mateo-Sagasta et al. 2017) and results "in decline of the biodiversity of microorganisms, algae, plants and animals" (Lorenz 2014; Mateo-Sagasta et al. 2017).

\subsubsection{Emerging Pollutants}

New "agricultural pollutants such as antibiotics, vaccines, growth promoters and hormones have emerged in the last two decades" (Mateo-Sagasta et al. 2017). These pollutants can reach water via "leaching and runoff from livestock" (Mateo-Sagasta 
et al. 2017) and "aquaculture farms, as well as through the application of manure and slurries to agricultural land" (OECD 2012; Mateo-Sagasta et al. 2017). Today, "more than 700 emerging pollutants and their metabolites and transformation products are listed as present in European aquatic environments" (Norman 2016; MateoSagasta et al. 2017). "Agriculture is not only a source of emerging pollutants, it also contributes to the spread and reintroduction of such pollutants into aquatic environments through wastewater reuse for irrigation and the application of municipal biosolids to land as fertilizers" (Mateo-Sagasta et al. 2017). "An estimated 35.9 Mha of agricultural lands are subjected to the indirect use of wastewater" (Thebo et al. 2017; Mateo-Sagasta et al. 2017). The "potential risks to human health posed by exposure to emerging pollutants via contaminated agricultural products needs attention" (Mateo-Sagasta et al. 2017).

\subsubsection{Sewage}

The greatest volume of "waste discharged into the aquatic ecosystems is sewage." Sewage contains "industrial wastes, municipal wastes and domestic wastes which include wastes from baths, washing machines, kitchens and faecal matter." Fresh water sources "serve as best sinks for the discharge of these wastes" (Das and Acharya 2003; Tukura et al. 2009). It is estimated that " $58 \%$ of the wastewater from urban areas and $81 \%$ of industrial wastes are discharged directly into water bodies with no or inadequate treatment results in contamination of $\sim 73 \%$ of the water bodies" (Vargas-Gonzalez et al. 2014). The release of "sewage has led to the increase in water pollution and depletion of clean water resources" (Avalon Global Research 2012). "Huge loads of such wastes are generated daily from highly populated cities and are finally washed out by the drainage systems which generally open into nearby rivers or aquatic systems" (Tukura et al. 2009). It has resulted in "extensive ecological degradation such as a decline in water quality and availability, intense flooding, loss of species, and changes in the distribution and structure of the aquatic biota" (Oberdorff et al. 2002). The "negative impact of sewage is based on the composition and concentration of the contaminants as well as the volume and frequency of wastewater effluents entering water bodies" (Akpor and Muchie 2011; Bhat et al. 2017). "Sewage is comprised of several microorganisms, heavy metals, nutrients, radionuclides, pharmaceutical, and personal care products." Sewage is primarily organic in nature; owing to the organic load of sewage, the "oxygen concentration in the receiving waters is reduced, thus sewage is said to have a high BOD." The "effect of maltreated sewage on surface water is largely determined by the oxygen balance of the aquatic ecosystem, and its presence is essential in maintaining biological life within the system" (DFID 1999; Morrison et al. 2001; Momba et al. 2006). "DO concentrations below $5 \mathrm{mg} / \mathrm{L}$ can have a negative effect on the living organisms in the aquatic ecosystem" (Momba et al. 2006). Low dissolved oxygen concentration can affect "functioning of some fish species and can eventually lead to the death of fish population" (Igbinosa and Okoh 2009; Mehmood et al. 2019). 
Decaying "organic matter" and "nutrients such as nitrites, nitrates, and phosphorus" in sewage can induce "eutrophication of water courses." "Eutrophication can lead to growth of plants and algae blooms" in the "aquatic ecosystem" (Bhat et al. 2017). "Algal blooms result in toxin production." Fish species "feeding in water contaminated" by "algal toxins will absorb these toxins and are subject to mass mortality" (Hernandez et al. 1998). Due to "eutrophication turbidity of the water increases, plant and animals' biomass increases, sedimentation rate increases, species diversity decreases, and anoxic conditions may develop, and this could give rise to change in dominant species of the aquatic biota" (Edokpayi 2016).

"Sewage effluent entering into surface waters contains a variety of pathogenic organisms that could result in the transmission of waterborne diseases when such contaminated water is used for domestic and other purposes" (WHO 2006; Chigor et al. 2013) thus is "detrimental to human health and the society at large" (DWA 1999). Some pathogens contaminate water resources (Mateo-Sagasta et al. 2017), via runoff (FAO 2006a; WHO 2012; Mateo-Sagasta et al. 2017). About "25\% of all deaths worldwide are the result of infectious diseases caused by pathogenic microorganisms" (UNEP 2006). Scientists have identified about "1400 species of microorganisms that can cause ill health, including bacteria, protozoa, protozoan parasites, parasitic worms, fungi, and viruses" (CSIR 2010). Some common "pathogens found in sewage" are presented in Table 1.2 (WHO 2006; Christou 2011).

\subsubsection{Heavy Metals}

"Heavy metals enter the aquatic ecosystem from both natural and anthropogenic sources." Entry may be as a result of "direct discharges into both fresh and marine ecosystems or through indirect routes such as atmospheric deposition and surface run-off" (Biney et al. 1994). Important "natural sources are volcanic activity and weathering of rocks." "Heavy metals are natural constituents of rocks and soils and enter the environment as a consequence of weathering and erosion" (Förstner 1987). Heavy metals in "aquatic system can be naturally produced by the slow leaching from soil/rock to water, which are usually at low levels, causing no serious lethal effects on human health" (Chang et al. 2000; Rashid et al. 2019). The "development of industry and agriculture promotes the rapid increase of heavy metal pollution. Aquatic heavy metal pollution usually represents high levels of Mercury, Chromium, Lead, Cadmium, Copper, Zinc, Nickel etc. in the water system". "Arsenic, Cadmium, Copper, Mercury and Zinc are the five metals with most potential impact that enter the environment in elevated concentrations through storm water and wastewater discharges as a consequence of agricultural and industrial activity" (Alloway 2013). They are important "group of toxic contaminants because of their high toxicity and persistence in all aquatic ecosystems." Zinc and copper are present in "fertilizers as impurities, while Arsenic, Cadmium and Mercury are constituents of some fungicides and algaecides" (Fifield and Haines 2000) (Table 1.3). 
Table 1.2 Microbial diseases associated with polluted aquatic environs

\begin{tabular}{|c|c|c|}
\hline Agent & Species & Disease \\
\hline Bacteria & $\begin{array}{l}\text { "Campylobacter jejune" } \\
\text { "Escherichia coli" } \\
\text { "E. coli } \mathrm{O} 157: \mathrm{H} 7 " \\
\text { "Helicobacter pylori" } \\
\text { "Salmonella sp." } \\
\text { "Salmonella typhi" } \\
\text { "Shigella sp." } \\
\text { "Vibrio cholera" }\end{array}$ & $\begin{array}{l}\text { "Gastroenteritis" } \\
\text { "Gastroenteritis" } \\
\text { "Bloody diarrhea, hemolytic uremic syndrome" } \\
\text { "Abdominal pain, peptic ulcers, gastric cancer" } \\
\text { "Salmonellosis, gastroenteritis, diarrhea" } \\
\text { "Typhoid fever" } \\
\text { "Dysentery" } \\
\text { "Cholera" }\end{array}$ \\
\hline Helminths & $\begin{array}{l}\text { "Ascaris lumbricoides } \\
\text { (round worm)" } \\
\text { "Clonorchis sinensis (liver } \\
\text { fluke)" } \\
\text { "Fasciola (liver fluke)" } \\
\text { "Fasciolopsis buski } \\
\text { (intestinal fluke)" } \\
\text { "Opisthorchis viverrini", } \\
\text { "Schistosoma (blood } \\
\text { fluke)" } \\
\text { "Trichuris (whim worm)" } \\
\text { "Taenia (tape worm)" }\end{array}$ & $\begin{array}{l}\text { "Ascariasis" } \\
\text { "Clonorchiasis" } \\
\text { "Fascioliasis" } \\
\text { "Fascioloidiasis" } \\
\text { "Opisthorchiasis" } \\
\text { "Schistosomiasis (bilharzia)" } \\
\text { "Trichuriasis" } \\
\text { "Taeniasis" }\end{array}$ \\
\hline Protozoa & $\begin{array}{l}\text { "Balantidium coli" } \\
\text { "Cryptosporidium } \\
\text { parvum" } \\
\text { "Cyclospora cayetanensis" } \\
\text { "Entamoeba histolytica" } \\
\text { "Giardia lamblia" }\end{array}$ & $\begin{array}{l}\text { "Balantidiasis (dysentery)" } \\
\text { "Cryptosporidiosis" } \\
\text { "Persistent diarrhea" } \\
\text { "Amoebiasis (amoebic dysentery)" } \\
\text { "Giardiasis" }\end{array}$ \\
\hline Viruses & $\begin{array}{l}\text { "Adenovirus" } \\
\text { "Astrovirus" } \\
\text { "Calicivirus" } \\
\text { "Coronavirus" } \\
\text { "Eneroviruses" } \\
\text { "Echovirus" } \\
\text { "Poliovirus" } \\
\text { "Hepatitis A and E" } \\
\text { "Parvovirus" } \\
\text { "Norovirus" } \\
\text { "Rotavirus" } \\
\text { "Coxsackieviruses" }\end{array}$ & $\begin{array}{l}\text { "Respiratory disease and eye infections" } \\
\text { "Gastroenteritis" } \\
\text { "Gastroenteritis" } \\
\text { "Gastroenteritis" } \\
\text { "Gastroenteritis" } \\
\text { "Fever, rash, respiratory and heart disease, aseptic } \\
\text { meningitis" } \\
\text { "Paralysis, aseptic meningitis" } \\
\text { "Infectious hepatitis" } \\
\text { "Gastroenteritis" } \\
\text { "Gastroenteritis" } \\
\text { "Gastroenteritis" } \\
\text { "Herpangina, aseptic meningitis, respiratory illness, } \\
\text { fever, paralysis, respiratory, heart and kidney disease" }\end{array}$ \\
\hline
\end{tabular}

Heavy metals have "high ecological significance because they are not removed from water, but accumulate in the water reservoirs and thus enter the food chain" (Loska and Wiechuła 2003). Under "certain environmental conditions," heavy metals may "accumulate to a highly toxic concentration and cause ecological damage" (Harguinteguy et al. 2014). Once released in aquatic environments, they are generally "bound to particulate matter, which eventually settle down and become incorporated into sediments and are released into the water under the suitable conditions 
Table 1.3 Different kinds of heavy metal discharge sources in aquatic environs (Fifield and Haines 2000)

\begin{tabular}{l|l}
\hline Metal & Sources \\
\hline Iron & "Pigments and paints, fuel, refineries, textile" \\
\hline Manganese and & $\begin{array}{l}\text { "Batteries and electrical, pigments and paints, alloys and solders, pesticides, } \\
\text { glass, fertilizers, refineries, fuel" }\end{array}$ \\
\hline Lead & $\begin{array}{l}\text { "Batteries and electrical, pigments and paints, alloys and solders, pesticides, } \\
\text { glass, fertilizers, refineries, fuel, plastic" }\end{array}$ \\
\hline Cadmium & $\begin{array}{l}\text { "Batteries and electrical, pigments and paints, alloys and solders, plastic, } \\
\text { fertilizers, fuel" }\end{array}$ \\
\hline Nickel & "Batteries and electrical, pigments and paints, alloys and solders, fertilizers, \\
& fuel, catalysts" \\
\hline Copper & $\begin{array}{l}\text { "Batteries and electrical, pigments and paints, alloys and solders, fertilizers, } \\
\text { pesticides, fuel, catalysts" }\end{array}$ \\
\hline Chromium & "Pigments, fertilizers, textile" \\
\hline
\end{tabular}

such as $\mathrm{pH}$ values and $\mathrm{Eh}$, leading to further contamination of aquatic environment" (Xu and Yang 1996). Accordingly, sediments represent one of the "ultimate sinks for heavy metals discharged into aquatic environment" (Gibbs 1973; Bryan and Langston 1992; Harguinteguy et al. 2014). "More and more attention has been drawn due to the wide spread occurrence of metal pollution in aquatic system" (Zhou et al. 2008). Some "heavy metals" may transform into the "persistent metallic compounds with high toxicity" (Zhou et al. 2008), which can be "bioaccumulated in the organisms" (Zhou et al. 2008), "magnified in the food chain, thus threatening human health" (Jin 1992; Zhou et al. 2008). "Various harmful effects including abnormal development of fetus, procreation failure, and immune deficiency has exhibited due to aquatic metal exposure" (Chang et al. 2000; Zhou et al. 2008). Some heavy metals, including mercury, chromium, cadmium, nickel, copper, and lead, introduced into water systems may pose high toxicities on the aquatic organisms (Wu and Zhao 2006). As an example, "cadmium is a priority environmental contaminant with consequences for human health and the maintenance of biodiversity in affected ecosystems" (Zhou et al. 2008) and "the timeliness of a broader, ecosystem-based approach to cadmium research is highlighted based on the overview of recent developments in the field" (Campbell 2006; Zhou et al. 2008).

\subsubsection{Eutrophication}

Eutrophication is a leading cause of destruction of many freshwater and marine ecosystems in the world. It is characterized by "excessive plant and algal growth due to the increased availability of one or more limiting growth factors needed for photosynthesis" (Schindler 2006), such as sunlight, carbon dioxide, and nutrients. "Eutrophication occurs naturally over centuries as lakes age and are filled in with sediments" (Carpenter 1981). However, "human activities have accelerated the rate 
and extent of eutrophication through both point-source discharges and non-point loadings of limiting nutrients, such as nitrogen and phosphorus, into aquatic ecosystems (i.e. cultural eutrophication), with dramatic consequences for drinking water sources, fisheries, and recreational water bodies" (Carpenter et al. 1998; Bhat et al. 2017). However, "during 1960s and 1970s, scientists linked algal blooms to nutrient enrichment resulting from anthropogenic activities such as agriculture, industry and sewage disposal" (Schindler 1974). The known "consequences of cultural eutrophication include blooms of blue-green algae (cyanobacteria), tainted drinking water supplies, degradation of recreational opportunities and hypoxia" (Bhat et al. 2017). The most obvious effect of cultural eutrophication is the creation of dense blooms of noxious, foul "smelling phytoplankton" that reduce water clarity and "harm water quality." "Algal blooms limit light penetration, reduce growth and cause death of plants in littoral zones and also lower the success of predators that need light to catch prey" (Lehtiniemi et al. 2005). Furthermore, high rates of photosynthesis associated with eutrophication can deplete dissolved inorganic carbon and raise $\mathrm{pH}$ to extreme levels during the day. "Elevated $\mathrm{pH}$ can in turn 'blind' organisms that rely on perception of dissolved chemical cues for their survival by impairing their chemosensory abilities" (Turner and Chislock 2010). When these "dense algal blooms eventually die, microbial decomposition severely depletes DO, creating a hypoxic dead zone, lacking sufficient oxygen to support most organisms." Dead zones are found in many "freshwater lakes including the Laurentian Great Lakes" (e.g., central basin of Lake Erie; Arend et al. 2011) during the summer. Furthermore, such "hypoxic events are particularly common in marine coastal environments surrounding large, nutrient-rich rivers" (e.g., Mississippi River and the Gulf of Mexico; Susquehanna River and the Chesapeake Bay) and have been shown to affect more than 245,000 square kilometers in over 400 near-shore systems (Diaz and Rosenberg 2008). "Hypoxia and anoxia as a result of eutrophication continue to threaten profitable commercial and recreational fisheries worldwide. Some algal blooms pose an additional threat because they produce noxious toxins" (e.g., microcystin and anatoxin-a) (Chorus and Bartram 1999). Over the past century, "harmful algal blooms (HABs) have been linked with (1) degradation of water quality" (Francis 1878), (2) "destruction of economically important fisheries" (Burkholder et al. 1992), and (3) "public health risks" (Morris 1999). Within freshwater ecosystems, "cyanobacteria are the most important phytoplankton associated with HABs" (Paerl 1988). "Toxigenic cyanobacteria, including Anabaena, Cylindrospermopsis, Microcystis, and Oscillatoria (Planktothrix), tend to dominate nutrient-rich, freshwater systems due to their superior competitive abilities under high nutrient concentrations, low nitrogen-to-phosphorus ratios, low light levels, reduced mixing, and high temperatures" (Downing et al. 2001; Paerl and Huisman 2009; Paerl and Paul 2012). Poisonings of "domestic animals, wildlife and even humans by blooms of toxic cyanobacteria" have been recognized throughout the world. Francis (1878) has first observed dead livestock due to "algal bloom of cyanobacteria" (Bhat et al. 2017). Also, cyanobacteria is responsible for several off-flavor compounds (e.g., methylisoborneal and geosmin) found in municipal drinking water systems as well as in aquaculture-raised fishes, resulting in large financial losses for state and 
regional economies (Crews and Chappell 2007). In addition to posing "significant public health risks, cyanobacteria have been shown to be poor quality food for most zooplankton grazers in laboratory studies" (Tillmanns et al. 2008; Wilson et al. 2006), thus reducing the efficiency of energy transfer in aquatic food webs and potentially preventing zooplankton from controlling algal blooms. Eutrophication is also associated with major changes in aquatic community structure. During "cyanobacterial blooms, small-bodied zooplankton tend to dominate plankton communities, and past observational studies have attributed this pattern to anti-herbivore traits of cyanobacteria" (e.g., toxicity, morphology, and poor food quality) (Porter 1977). However, the biomass of planktivorous fish is often positively related to nutrient levels and ecosystem productivity. Piscivorous fishes (e.g., bass, pike) tend to dominate the fish community of nutrient-poor, oligotrophic lakes, while planktivorous fishes (e.g., shad, bream) become increasingly "dominant with nutrient enrichment" (Jeppesen et al. 1997). Thus, an alternative explanation for the lack of zooplankton control of cyanobacterial blooms could include consumption of zooplankton by planktivores.

\subsubsection{Plastics and Microplastics}

Among the several human pressures on aquatic ecosystems, the accumulation of plastic debris is one of the most apparent but least studied. "Plastics generate significant benefits to the human society" (Andrady and Neal 2009), but due to its "durability, unsustainable use and inappropriate waste management plastics accumulate extensively in the natural habitats" (Barnes et al. 2009). Because of "high mobility, plastic debris has practically permeated the global marine environment" (Cole et al. 2011; Ivar do sul and Costa 2014), including the "polar region" (Barnes et al. 2009), "mid-ocean islands" (Ivar do sul et al. 2013), and "the deep sea" (Van Cauwenberghe et al. 2013). The sources of marine plastics are not very well characterized. A rough estimation predicts that " 70 to $80 \%$ of marine litter, most of it is plastics, originate from inland sources and are emitted by rivers to the oceans" (GESAMP 2010). Rivers transport considerable amounts of plastics and "thus contribute significantly to the marine plastics pollution" (Moore et al. 2005; Lechner et al. 2014). "Plastics are dumped in huge volumes in beaches, lakes, navigation channels and other forms of water masses" (Lechner et al. 2014). The volume of plastic is even bigger in lowincome countries with poor waste disposal regulations. In the marine environment, "plastics of various size classes and origins are omnipresent and affect numerous species that become entangled in or ingest plastics as well as an aesthetic problem" (Gregory 1999, 2009). "Plastics have been reported as a problem in the marine environment since the 1970s, but only recently the issue of plastic pollution in marine and freshwater environments been identified as a global problem" (Carpenter and Smith 1972). It has been reported that "single-use plastics (plastic bags and micro beads) are a major source of this pollution" (Desforges et al. 2014; Perkins 2015). 
Under environmental conditions, larger plastic items degrade to so-called microplastics (MPs), typically smaller than $5 \mathrm{~mm}$ in diameter. "MPs are considered an emerging global issue by various experts" (Sutherland et al. 2010; Depledge et al. 2013) and international institutions (GESAMP 2010; UNEP 2011). Recent studies suggest that "risks of microplastics in the marine environment may pose more threat than macroplastics" (Thompson 2015; Diamond et al. 2018).

Potential sources of "MPs include wastewater treatment plants, runoff from urban, agricultural, touristic, and industrial areas, as well as shipping activities, beach litter, fishery and harbors" (Zubris and Richards 2005; Norén 2007; GESAMP 2010; Claessens et al. 2011; Dubaish and Liebezeit 2013). Another "potential source is sewage sludge that typically contains more MPs than effluents" (Leslie et al. 2012). A "broad spectrum of aquatic organisms are prone to MP ingestion ranging from plankton and fish to birds and even mammals, and accumulate throughout the aquatic food web" (Wright et al. 2013). Due to their large "surface-to-volume ratio and chemical composition, MPs accumulate environmental chemicals from the surrounding environment including metals" (Ashton et al. 2010) and "persistent, bioaccumulative, and toxic compounds" (Koelmans et al. 2013) transferring these contaminants from water to biota. "Plastic particles are also dominated by certain human pathogens like specific members of the genus Vibrio". Therefore, MPs can act as a vector for waterborne "human pathogens" influencing the water quality. In addition, "plastics contain and release a multitude of chemical additives" (Rochman 2013; Dekiff et al. 2014) and adsorb organic contaminants from the surrounding media (Bakir et al. 2012). Compounds such as MPs can transfered to organisms upon ingestion (Zarfl and Matthies 2010), this may increase "the chemical exposure of the ingesting organism and thus, toxicity" (Oehlmann et al. 2009; Teuten et al. 2009).

\subsubsection{Oil Spills}

An "oil spill" is defined as the discharge of "liquid petroleum hydrocarbons" into the environment, mainly in the "marine ecosystem" caused by human activity. "Environmental pollution caused by an oil spill is detrimental" (Broekema 2016). This is because "petroleum hydrocarbons are toxic to all forms of life and harm both aquatic and terrestrial organisms." The pollution of marine environments has caught the attention of researchers and environmentalists. This is due to the severe impact of oil spills on marine life. "A $1 \%$ increase in spill size has been estimated to increase the damage by some US\$0.718 million" (Alló and Loureiro 2013). "Oil spills, which result from damage, transportation accidents and various other industrial and mining activities, are classified as hazardous waste" (Bartha and Bossert 1984). They are considered to be the most "frequent organic pollutants of aquatic ecosystems" (Bossert et al. 1984; Margesin and Schinnur 1997). Oil spills can occur from multiple sources including "oil tankers" (35.7\%), facilities (27.6\%), "non-tank ves- 
sels" (19.9\%), "pipelines" (9.3\%), and other sources (7.4\%) (Benko and Drewes 2008). "Marine ship-source oil spill can occur as a result of ship accidents or operations, or the intentional discharge of oily wastes into oceans" (Knapp and Van de Velden 2011).

\subsubsection{Major Oil Spills in the History}

It is estimated that " 3.2 million tons of oil is released per year from all sources into the environment. The majority of this oil is due to general shipping and industrial activities" (ITOPF 1990). During the Iran-Iraq war (1980-1988), approximately 2 million barrels of oil were discharged into the Arabian Gulf sea water. These included "1.5 million barrels from the Nawruz blow-out in 1983" (Watt 1994). Following the "Gulf War in 1991, 4 to 8 million barrels of oil were released into the Gulf and the Kuwaiti Desert and, making this the largest oil spill in the history at that time" (Purvis 1999). Previous observations indicated that the number of large "oil spills (>700 tons) has decreased significantly over the last 30 years" (ITOPF 1990). During the 1990s, the average number of large oil spills per year was about a third of the amount that was witnessed during the 1970s. It should be noted that "1,133,000 tons of oil was lost in the 1990s and 2000s, during 2010-2013, about 22,000 tons of oil was lost" (Levy and Gopalakrishnan 2010; Carriger and Barron 2011). The BP Deepwater Horizon oil spill on April 20, 2010, caused the discharge of more than 2.6 million gallons of oil into the Gulf of Mexico over just about 3 months. This "oil spill was the second largest in human history" (Levy and Gopalakrishnan 2010; Carriger and Barron 2011). During the 1991 Gulf War, the deliberate release of "over 6 million barrels of oil" (Randolph et al. 1998) into the marine environment was considered as the largest in history.

\subsubsection{Impact on Human Health}

Oil spills pose a great danger to humans. Direct "contact with crude oil or indirect contact through inhalation of vapors or consumption of contaminated seafood can cause deleterious health effects ranging from dizziness and nausea to certain types of cancers and issues with the central nervous system" (Aguilera et al. 2010; Major and Wang 2012). Toxic chemicals contained in the oil such as benzenes, toluene, poly-aromatic hydrocarbon, and oxygenated polycyclic aromatic hydrocarbons can harm the air quality (Tidwell et al. 2015). As witnessed in the "Kuwait Oil Fires, between January 16, 1991 and November 6, 1991, produced air pollution which caused respiratory distress" (Petruccelli et al. 1999). Oil-related disasters cause water contamination when the oil spillage comes in contact with any drinking water supply, for example, the 2013 incident in Miri, Malaysia, contaminated the water supply for 300,000 natives. 


\subsubsection{Impact on Coral Reefs}

Coral reefs are considered to be important components of marine ecosystems. This is because "coral polyps are important nurseries for shrimp, fish and other animals" (Perkol-Finkel and Benayahu 2007). The aquatic organisms that live within and around the coral reefs are at risk of exposure to the toxic substances within oil. They are rapidly degrading because of a variety of environmental and anthropogenic pressures. Thus, they are suffering significant changes in "species diversity," "species abundance," "species evenness," and "habitat structure" worldwide (Hughes et al. 2007). "Oil dispersants are potentially harmful to marine life including coral reefs" (Shafir et al. 2007). A study using coral nubbins in coral reef eco-toxicology testing (Shafir et al. 2003) found that dispersed oil and oil dispersants are harmful to soft and hard coral species at early life stages.

\subsubsection{Impact on Marine Mammals}

Marine mammals include "bottlenose dolphins, fins, humpbacks, rights, sei whales, sperm whales, manatees, cetaceans, seals, sea otters and pinnipeds." The physical contact of oil with furred mammals affects these animals because they rely on their outer coats for buoyancy and warmth. Consequently, "these animals often succumb to hypothermia, drowning and smothering when oil flattens and adheres to the outer layer" (Lin and Tjeerdema 2008).

\subsubsection{Impact on Seabirds}

Physical contact is one of the major routes of exposure, and it usually affects seabirds (Table 1.4). For example, thousands of African penguins (Spheniscus demerus) were oiled following the 2000 treasure oil spill in South Africa.

\subsubsection{Aquaculture Activities}

Aquaculture is the farming of aquatic organisms. The "rapidly growing human population is creating an increase in the demand for fish worldwide" (Tidwell and Allan 2001). The amount of "fish captured in fisheries is no longer meeting this demand because the annual production of captured fish has not changed significantly since 2011" (FAO 2016b). "Aquaculture is becoming a more popular fish production method as it has an annual increase of $6 \%$ and is projected to produce over half of the fish consumed by 2025" (FAO 2016b). "Aquaculture has tremendous benefits for the humans like seafood production by fisheries and contributes with 15 to $20 \%$ of average animal protein consumption to 2.9 billion people worldwide" (Smith et al. 2010). The nutritional quality of aquatic products has "high standard and 
Table 1.4 Mass motility of seabirds collected at "Exxon Valdez and Braer oil spills" (Dauvin 1998)

\begin{tabular}{l|l|l}
\hline "Species group" & "Alaskan spill" & "Shetland spill" \\
\hline "Sea ducks (eiders, etc.)" & $1435-1445$ & 168 \\
\hline "Mergansers" & $120-125$ & $1-2$ \\
\hline "Loons" & $390-400$ & $12-15$ \\
\hline "Grebes" & $460-462$ & 0 \\
\hline "Heron" & 1 & $2-4$ \\
\hline "Geese/swans" & $8-10$ & 0 \\
\hline "Gulls" & $694-698$ & $72-76$ \\
\hline "Kittiwakes" & $1220-1230$ & $130-135$ \\
\hline "Cormorants/shags" & $835-837$ & $862-865$ \\
\hline "Shearwaters" & 3400 & 0 \\
\hline "Fulmars" & $868-872$ & $30-32$ \\
\hline "Guillemots/murres" & $20,560-20,562$ & $218-222$ \\
\hline "Other auks" & $2172-2176$ & $228-230$ \\
\hline "Bald eagles" & $124-126$ & $\mathrm{NA}$ \\
\hline "Other birds" & $3150-3153$ & 0 \\
\hline Total & $35,466-35,468$ & $1535-1538$ \\
\hline
\end{tabular}

represents an important source of macro and micronutrients for the people from developing countries" (Roos et al. 2007). Despite the undeniable benefits of aquaculture such as the provision of good quality and accessible food for population and the generation of millions of jobs and billion dollars in budget for the developing countries, the activity is one of the most criticized worldwide, mainly because of the environmental impacts (FAO 2016c). The most common "negative environmental impacts that are associated with aquaculture is water eutrophication, water quality, alteration or destruction of natural habitats, introduction and transmission of diseases" (FAO 2006b).

\subsubsection{Harmful Impacts Related to the Aquaculture Activities Are as Follows}

\subsubsection{Eutrophication of Receiving Waters}

Aquaculture can be "a major contributor to eutrophication or organic loads in the receiving waters" (Mateo-Sagasta et al. 2017). It is mainly produced by "uneaten feed (especially due to overfeeding), lixiviation of aquaculture feedstuffs" (Focardi et al. 2005; Crab et al. 2007), "decomposition of died organisms and over fertilization" (Feng et al. 2004; Gyllenhammer and Hakanson 2005). In Scotland, for example, "the discharge of untreated organic waste from salmon production is equivalent to $75 \%$ of the pollution discharged by the human population" (Mateo-Sagasta et al. 2017). "Shrimp aquaculture in Bangladesh generates 600 tons of waste per day" 
(SACEP 2014; Mateo-Sagasta et al. 2017). It is well documented that from "the total nitrogen supplemented to the cultured organisms, only $20-50 \%$ is retained as biomass by the farmed organisms, while the rest is included into the water column or sediment" (Jackson et al. 2003; Schneider et al. 2005) and "eventually discharged into the receiving ecosystems, increases the risk of eutrophication and algal blooms (like toxic microalgae-red tides) in lakes" (Mateo-Sagasta et al. 2017), reservoirs, and coastal areas (Alonso-Rodriguez and Paez-Osuna 2003; Mirto et al. 2009; Mateo-Sagasta et al. 2017). "Organic pollutants consume dissolved oxygen (DO) in the water as it degrades quality characteristics of fresh water, with the result DO drops, fish and other aquatic life are exposed to extreme conditions or killed due to hypoxia in water bodies" (Mateo-Sagasta et al. 2017).

\subsubsection{Introduction of Exotic Species}

Aquaculture comes in multiple versions, two of which are open systems and closed systems. "Open systems are found offshore in coastal areas, exposed to natural environments" (Lawson 1995). These systems are high-risk because they allow unchecked interactions between the farmed fish and surrounding environment, which leads to "free exchange of diseases, parasites and fecal matter" (Ali 2006). The recent study has revealed "a parasite transmission of sea lice from captive to wild salmon" (Krkosek et al. 2007). The only barrier between the harvested fish and the wild population is a rigid cage or netting system. When these netting systems are damaged during inclement weather such as snowstorms or hurricanes, it allows "fish to escape from the open systems" (Centre for Food Safety 2012). There were " 25 million reported fish escapes worldwide and the majority occurred when netting was damaged during severe weather conditions" (Centre for Food Safety 2012). The escaping of "exotic aquaculture species into the natural ecosystem causes the displacement of native populations, competition for food, space, mates and prey" (Naylor et al. 2005).

\subsubsection{Destruction of Mangrove Forests}

"Aquaculture farms" are constructed in "mangrove forests" (Dewalt et al. 2002; Stickney and McVey 2002; Rajitha et al. 2007). "Mangrove forests" are important ecosystems as they act as nurseries for many "aquatic species" as well as nesting areas for "birds, reptiles, crustaceans and other taxonomic groups" (Paez-Osuna 2005). The cover of mangrove forest has decreased worldwide from " 19.8 million hectares in 1980 to less than 15 millions hectares in 2000." The annual "deforestation rate was 1.7\% from 1980 to 1990 and 1\% from 1990 to 2000" (FAO 2007), and the "problem of deforestation still continue today." "Aquaculture has been responsible for the deforestation of millions of hectares of mangrove forest in Thailand, Indonesia, Ecuador, Madagascar and other countries" (Harper et al. 2007). 


\subsubsection{Contamination of Water for Human Consumption}

"Inland aquaculture" has been responsible for the "degradation of water bodies used for human consumption" (Paez-Osuna 2001). Aquaculture activities cause death of benthic organisms as well as undesirable odors and the presence of pathogens in the discharge sites (Martinez-Cordova and Enriquez-Ocana 2007). The spread and the "outbreaks of diseases are negative consequences of the expansion and diversification of the aquaculture sector" (Crisafi et al. 2011; Mancuso 2013; Mancuso et al. 2013).

\subsubsection{Preventive Measures and some Humanistic Solutions}

"Water contamination" can be reduced from a "personal level" to "national and international level." Every individual has a duty to prevent pollution of water resources. "Water is a basic need for our survival," and hence it should be our first priority to keep all "water resources" free from contamination. There are various "sources of water contamination." Thus, the control of water contamination needs a range of preventive measures. "Measures of prevention and control are essential in improving the quality of water" and reducing the "costly treatment measures that are taken to treat water." Preventive measures and possible solutions to "control water contamination" are given as follows (Xiong et al. 2015; Lan et al. 2015; Xanthos and Walker 2017; Barmentlo et al. 2018):

- "Do not throw rubbish away in places like the beach, riverside and water bodies rather put it in trash can."

- "Use water wisely. Do not keep the tap running when not in use."

- "Do not throw chemicals, oils, plastics, paints and medicines down the sink drain, or the toilet."

- "Buy more environmentally safe cleaning liquids for use at home and other public places."

- "Not to overuse pesticides and fertilizers in farms. This will reduce runoffs of the chemical into nearby water sources."

- "Natural fertilizers such as peat, compost, manure should be preferred while gardening and farming."

- "Implementing water quality laws they can help in protecting aquatic ecosystems by imposing acceptable concentrations of pollutants and prevents the release of pollutants into water resources."

- "Proper use and disposeal of chemicals prevent the contamination of aquatic environments."

- "Use detergents with low or no phosphate because high phosphate content causes eutrophication of lakes."

- "Control storm water runoff. As the storm water runoff flows over impervious surfaces, it collects debris, sediments, chemicals and other pollutants which can have negative effects on the quality of water if the runoff is left untreated." 
- "Decrease water resistant surfaces such as cement around homes to reduce surface runoff. Vegetation, porous materials, gravel, wood decking etc. can be used instead of cement."

- "Avoid throwing garbage into lakes, rivers and streams and help in cleaning litter around water resources."

- "Wash your automobiles at carwashes instead of washing it yourself. The wastewater from these carwashes is drained into the sewer and treated which reduce the amount of pollutants in the water."

- "Speak up against industries that dump waste into local streams, rivers, and beach fronts to reduce water pollution in your community."

- "Implement existing environmental laws. There are very strict laws that help minimize water pollution. These laws are usually directed at industries, hospitals, schools and market areas on how to dispose, treat and manage sewage."

- "Do not dispose non-degradable products such as plastic bags or plastic wrappers down the drain."

\subsection{Conclusion}

The degradation of aquatic ecosystems is largely due to human activities. Increased urbanization and industrialization are greatly responsible for water pollution. Human contribution to water pollution is enormous, such as dumping of solid wastes, industrial wastes, and domestic wastes. Water pollution is a major concern to the world. Environmental education is very important to reduce the pollution of aquatic ecosystems.

\section{References}

Abowel JFN, Sikoki FD (2005) Water pollution management and control. Double Trust, Port Harcourt

Aguilera F, Méndez J, Pásaro E, Laffon B (2010) Review on the effects of exposure to spilled oils on human health. J Appl Toxicol 30(4):291-301

Akpor OB, Muchie M (2011) Environmental and public health implications of wastewater quality. Afr J Biotechnol 10(13):2379-2387

Al Naggar Y, Naiem E, Mona M, Giesy J, Seif A (2014) Metals in agricultural soils and plants in Egypt. Toxicol Environ Chem 96(5):730-742

Ali AMS (2006) Rice to shrimp: land use/land cover changes and soil degradation in southwestern Bangladesh. Land Use Policy 23:421-435

Alló M, Loureiro ML (2013) Estimating a meta-damage regression model for large accidental oil spills. Ecol Econ 86:167-175

Alloway BJ (2013) Introduction: in heavy metals in soils. Springer, Dordrecht, pp 3-9

Alonso-Rodriguez R, Paez-Osuna F (2003) Nutrients, phytoplankton and harmful algal blooms in shrimp ponds: a review with special reference of the situation in the Gulf of California. Aquaculture 219(1-4):317-336 
Andrady AL, Neal MA (2009) Applications and societal benefits of plastics. Philos Trans R Soc Lond Ser B Biol Sci 364:1977-1984

Arend KK, Beletsky D, DePinto J, Ludsin SA, Roberts JJ (2011) Seasonal and inter annual effects of hypoxia on fish habitat quality in Central Lake Erie. Freshwat Biol 56:366-383

Ashton K, Holmes L, Turner A (2010) Association of metals with plastic production pellets in the marine environment. Mar Pollut Bull 60:2050-2055

Avalon Global Research (2012) Water and waste water treatment opportunity in India: an overview

Bakir A, Rowland SJ, Thompson RC (2012) Competitive sorption of persistent organic pollutants onto microplastics in the marine environment. Mar Pollut Bull 64:2782-2789

Barange M, Field JG, Harris RP, Eileen E, Hofmann EE, Perry RI, Werner F (2010) Marine ecosystems and global change. Oxford University Press, Oxford, p 464

Barmentlo SH, Schrama M, Hunting ER, Heutink R, van Bodegom PM, de Snoo GR, Vijver MG (2018) Assessing combined impacts of agrochemicals: aquatic macroinvertebrate population responses in outdoor mesocosms. Sci Total Environ 631:341-347

Barnes DK, Galgani F, Thompson RC, Barlaz M (2009) Accumulation and fragmentation of plastic debris in global environments. Philos Trans R Soc Lond Ser B Biol Sci 364:1985-1998

Bartha R, Bossert I (1984) The treatment and disposal of petroleum refinery wastes. In: Atlas RM (ed) Petroleum microbiology. Macmillan, New York, pp 1-61

Benko KL, Drewes JE (2008) Produced water in the Western United States: geographical distribution, occurrence, and composition. Environ Eng Sci 25:239-246

Bhat RA, Shafiq-ur-Rehman MMA, Dervash MA, Mushtaq N, Bhat JIA, Dar GH (2017) Current status of nutrient load in Dal Lake of Kashmir Himalaya. J Pharmacog Phytochem 6(6):165-169

Bhat RA, Beigh BA, Mir SA, Dar SA, Dervash MA, Rashid A, Lone R (2018) Biopesticide techniques to remediate pesticides in polluted ecosystems. In: Wani KA, Mamta (eds) Handbook of research on the adverse effects of pesticide pollution in aquatic ecosystems. IGI Global, Hershey, PA, pp 387-407

Biney C, Amuzu AT, Calamari D, Kaba N, Mbome IL, Naeve H, Ochumba PB, Osibanjo O, Radegonde V, Saad MA (1994) Review of heavy metals in the African aquatic environment. Ecotoxicol Environ Saf 28(2):134-159

Bossert ID, Kachel WM, Bartha R (1984) Fate of hydrocarbons during oily sludge disposal in soil. Appl Environ Microbiol 47:763-767

Broekema W (2016) Crisis-induced learning and issue politicization in the Eu: the Braer, sea empress, Erika and prestige oil spill disasters. Public Adm 94:381-398

Bryan GW, Langston WJ (1992) Bioavailability, accumulation and effects of heavy metals in sediments with special reference to United Kingdom estuaries: a review. Environ Pollut 76(2):89-131

Burkholder JM, Noga EJ, Hobbs CH Jr, Glasgrow HB (1992) New 'phantom' dinoflagellate is the causative agent of major estuarine fish kills. Nature 358:407-410

Campbell PGC (2006) Cadmium-a priority pollutant. Environ Chem 3:387-388

Carpenter SR (1981) Submerged vegetation: an internal factor in lake ecosystem succession. Am Nat 118:372-383

Carpenter EJ, Smith KL (1972) Plastics on the Sargasson Sea surface. Science 175(4027):1240-1241

Carpenter SR, Caraco NF, Correl DL, Howarth RW, Sharpley AN, Smith VH (1998) Nonpoint pollution of surface waters with phosphorus and nitrogen. Ecol Appl 8:559-568

Carriger J, Barron MG (2011) Minimizing risks from spilled oil to ecosystem services using influence diagrams: the Deepwater horizon response. Environ Sci Technol 45:7631-7639

Centre for Food Safety (2012) Reported escapes from fish farm

Chang XX, Wen CH, Wang HJ (2000) Effect of heavy metal pollution on human health and sustainable development. Yunnan Environ Sci 19:59-61

Chigor VN, Sibanda T, Okoh AI (2013) Studies on the bacteriological qualities of the Buffalo River and three source water dams along its course in the eastern Cape Province of South Africa. Environ Sci Pollut Res 20:4125-4136

Chorus I, Bartram J (1999) Toxic cyanobacteria in water: a guide to their public health consequences, monitoring, and management. E \& FN Spon, London 
Christou L (2011) The global burden of bacterial and viral zoonotic infections. Clin Microbiol Infect 17(3):326-330

Claessens M, De Meester S, Van Landuyt L, De Clerck K, Janssen CR (2011) Occurrence and distribution of microplastics in marine sediments along the Belgian coast. Mar Pollut Bull 62:2199-2204

Cole M, Lindeque P, Halsband C, Galloway TS (2011) Microplastics as contaminants in the marine environment: a review. Mar Pollut Bull 62:2588-2597

Crab R, Avnimelech Y, Defoirdt T, Bossier P, Verstraete W (2007) Nitrogen removal techniques in aquaculture for a sustainable production. Aquaculture 270(1-4):1-14

Crews JR, Chappell JA (2007) Agriculture and natural resources U.S. catfish industry outlook. Auburn University, Auburn, AL

Crisafi F, Denar R, Genovese M, Cappello S, Mancuso M, Genovese L (2011) Comparison between 16SrDNA and ToxR genes as targets for the detection of vibrio anguillarum in Dicentrarchus labrax kidney and liver. Res Microbiol 162:223-230

CSIR (2010) A CSIR perspective on water in South Africa. CSIR report no. CSIR/NRE/PW/ IR/2011/0012/A

Das J, Acharya BC (2003) Hydrology and assessment of lotic water quality in Cuttack City, India. Water Air Soil Pollut 150:163-175

Dauvin JC (1998) The fine sand abra alba community of the Bay of Morlaix twenty years after the Amoco Cadiz oil spill. Mar Pollut Bull 36:669-676

Dekiff JH, Remy D, Klasmeier J, Fries E (2014) Occurrence and spatial distribution of microplastics in sediments from Norderney. Environ Pollut 186:248-256

Demirak A, Yilmaz F, Levent Tuna A, Ozdemir N (2006) Heavy metals in water, sediment and tissues of Leuciscus cephalus from a stream in southwestern Turkey. Chemosphere 63(9):1451-1458

Depledge MH, Galgani F, Panti C, Caliani I, Casini S, Fossi MC (2013) Plastic litter in the sea. Mar Environ Res 92:279-281

Desforges JP, Galbraith M, Dangerfield N, Ross PS (2014) Widespread distribution of microplastics in subsurface seawater in the NE Pacific Ocean. Mar Pollut Bull 79(1-2):94-99

Dewalt BR, Ramirez-Zavala JR, Noriega L, Gonzalez E (2002) Shrimp aquaculture, the people and the environment in coastal Mexico, Tech. Rep., World Bank, NACA, WWF y FAO consortium program on shrimp farming and the environment

DFID (1999) In: Pearce GR, Chaudhry MR, Ghulum S (eds) A simple methodology for water quality monitoring. Department for International Development, Wallingford, p 100

Diamond J, Altenburger R, Coors A, Dyer SD, Focazio M, Kidd K, Tolls J (2018) Use of prospective and retrospective risk assessment methods that simplify chemical mixtures associated with treated domestic wastewater discharges. Environ Toxicol Chem 37(3):690-702

Diaz RJ, Rosenberg R (2008) Spreading dead zones and consequences for marine ecosystems. Science 321:926-929

Don-pedro KN (1990) Pesticide pollution-biological resources for control and management. In: Proceedings of the conference on pesticide pollution detection and management at the University of Agriculture, Abeokuta, Nigeria

Downing JA, Watson SB, McCauley E (2001) Predicting cyanobacteria dominance in lakes. Can J Fish Aquat Sci 58:1905-1908

Dubaish F, Liebezeit G (2013) Suspended microplastics and black carbon particles in the jade system, southern North Sea. Water Air Soil Pollut 224:1352

DWA (1999) Wastewater limit values applicable to the discharge of wastewater into a river resource. National Water Act, Government Gazette No. 20528

Edokpayi JN (2016) Assessment of the efficiency of wastewater treatment facilities and the impact of their effluent on surface water and sediments in Vhembe District, South Africa, $\mathrm{PhD}$ thesis submitted to the University of Venda, South Africa

Ekubo AJ, Abowel JFN (2011) Aspects of aquatic pollution in Nigeria. Res J Environ Earth Sci 3:673-693 
FAO (2006a) Food and Agriculture Organization of the United Nations, Livestock's Long Shadow, Rome

FAO (2006b) State of world aquaculture, FAO fisheries technical paper no. 500, Rome, p 134

FAO (2007) El estadomundial de la pesca y acuicultura, Rome, Italy

FAO (2011) Food and Agriculture Organization of the United Nations (FAO) and London, the state of the world's land and water resources for food and agriculture, Earthscan, Rome

FAO (2013) Guidelines to control water pollution from agriculture in China, Water report 40

FAO (2016a) Food and Agriculture Organization of the United Nations (FAO). FAOSTAT, Rome

FAO (2016b) The state of world fisheries and aquaculture, contributing to food security and nutrition for all. Food and Agriculture Organization of United Nations, Rome, p 200

FAO (2016c) The state of world fisheries and aquaculture, contributing to food security and nutrition for all. Food and Agriculture Organization, UN, Rome

Feng YY, Hou LC, Ping NX, Ling TD, Kyo CI (2004) Development of mariculture and its impacts in Chinese coastal waters. Rev Fish Biol Fish 14(1):1-10

Fernandesa C, Fontainhas FA, Peixotoc F, Salgadod MA (2007) Bioaccumulation of heavy metals in Liza saliens from the Esmoriz -Paramos coastal lagoon, Portugal. Ecotoxicol Environ Saf 66(3):426-431

Fifield FW, Haines PJ (2000) Environmental analytical chemistry. Wiley-Blackwell, Hoboken, NJ

Focardi S, Corsi I, Franchi E (2005) Safety issues and sustainable development of European aquaculture: new tools for environmentally sound aquaculture. Aquacult Int 13(1-2):3-17

Förstner U (1987) Metal speciation in solid wastes-factors affecting mobility, speciation of metals in water, sediment and soil systems. Springer, Berlin, Heidelberg, pp 11-41

Francis G (1878) Poisonous Australian lake. Nature 18:11-12

GESAMP (2010) IMO/FAO/UNESCO-IOC/UNIDO/WMO/IAEA/UN/UNEP Joint Group of Experts on the Scientific Aspects of Marine Environmental Protection. In: Proceedings of the GESAMP international workshop on micro-plastic particles as a vector in transporting persistent, bio-accumulating and toxic substances in the oceans

Ghani SAA (2015) Trace metals in seawater, sediments and some fish species from MarsaMatrouh beaches in North-Western Mediterranean coast, Egypt. Egypt J Aquat Res 41(2):145-154

Gibbs RJ (1973) Mechanisms of trace metal transport in rivers. Science 180(4081):71-73

Gregory MR (1999) Plastics and South Pacific Island shores: environmental implications. Ocean Coast Manag 42:603-615

Gregory MR (2009) Environmental implications of plastic debris in marine settings: entanglement, ingestion, smothering, hangers-on, hitch-hiking and alien invasions. Philos Trans R Soc Lond B Biol Sci 364:2013-2025

Gyllenhammer A, Hakanson L (2005) Environmental consequence analyses of fish farm emissions related o different scales and exemplified by data from the Baltic_a review. Mar Environ Res 60(2):211-243

Halpern BS, Walbridge S, Selkoe KA, Kappel CV, Micheli F, D’agrosa C, Fujita R (2008) A global map of human impact on marine ecosystems. Science 319(5865):948-952

Hampel M, Blasco J, Segner H (2015) Molecular and cellular effects of contamination in aquatic ecosystems. Environ Sci Pollut Res 22:17261-17266

Harguinteguy CA, Cirelli AF, Pignata MI (2014) Heavy metal accumulation in leaves of aquatic plant Stuckenia filiformis and its relationship with sediment and water in the Suquía river (Argentina). Microchem J 114:111-118

Harper GJ, Steininger MK, Tucker CJ, Juhn D, Hawkins F (2007) Fifty years of deforestation and forest fragmentation in Madagascar. Environ Conserv 34(4):325-333

Herbert ER, Boon P, Burgin AJ, Neubauer SC, Franklin RB, Ardón M, Hopfensperger KN, Lamers LPM, Gell P (2015) A global perspective on wetland salinization: ecological consequences of a growing threat to freshwater wetlands. Ecosphere 6(10):1-43

Hernandez M, Robinson I, Aguilar A, Gonzalez LM, Lopez- Jurado LF, Reyero MI, Cacho E, Franco J, Lopez-Rodas V, Costas E (1998) Did algal toxins cause monk seal mortality. Nature 393:28-29 
Hughes TP, Rodrigues MJ, Bellwood DR, Ceccarelli D, Hoegh-Guldberg O, McCook L, Moltschaniwskyj N, Pratchett MS, Steneck RS, Willis B (2007) Phase shifts, herbivory and the resilience of coral reefs to climate change. Curr Biol 17:360-365

Hughes SR, Kay P, Brown LE (2013) Global synthesis and critical evaluation of pharmaceutical data sets collected form river systems. Environ Sci Technol 47:661-677

Igbinosa EO, Okoh AI (2009) The impact of discharge wastewater effluents on the physiochemical qualities of a receiving watershed in a typical rural community. Int J Environ Sci Technol 6(2): $175-182$

ITOPF (1990) Response to marine oil spills. Wither by, International Tanker Owners Pollution Federation, London

Ivar do Sul JA, Costa MF (2014) The present and future of microplastic pollution in the marine environment. Environ Pollut 185:352-364

Ivar do Sul JA, Costa MF, Barletta M, Cysneiros FJ (2013) Pelagic microplastics around an archipelago of the equatorial Atlantic. Mar Pollut Bull 75:305-309

Jackson C, Preston N, Thompson PJ, Burford M (2003) Nitrogen budget and effluent nitrogen components at an intensive shrimp farm. Aquaculture 218(1-4):397-411

Jeppesen E, Jensen JP, Sondergaard M, Lauridsen T, Pedersen LJ, Jensen L (1997) Top-down control in freshwater lakes: the role of nutrient state, submerged macrophytes and water depth. Hydrobiologia 342(343):151-164

Jin L (1992) Environmental bionomy, 1st edn. High Education Press, Beijing

Knapp S, Van de Velden M (2011) Global ship risk profiles: safety and the marine environment. Trans Res D Trans Environ 16(8):595-603

Koelmans AA, Besseling E, Wegner A, Foekema EM (2013) Plastic as a carrier of POPs to aquatic organisms: a model analysis. Environ Sci Technol 47:7812-7820

Krkosek M, Ford JS, Morton A, Lele S, Myers RA, Lewis A (2007) Declining wild salmon populations in relation to parasites from farm salmon. Science 318(5857):1772-1775

Lan D, Liang B, Bao C, Ma M, Xu Y, Yu C (2015) Marine oil spill risk mapping for accidental pollution and its application in a coastal city. Mar Pollut Bull 96(1-2):220-225

Larsson DGJ (2014) Pollution from drug manufacturing: review and perspectives. Phil Trans R Soc Lond B Biol Sci 369(1656):20130571

Lawson TB (1995) Aquaculture in open systems. In: Fundamentals of aquacultural engineering. Springer, Boston, MA, pp 58-83

Lechner A, Keckeis H, Lumesberger-Loisl F, Zens B, Krusch R, Tritthart M, Glas M, Schludermann E (2014) The Danube so colourful: a potpourri of plastic litter outnumbers fish larvae in Europe's second largest river. Environ Pollut 188:177-181

Lehtiniemi M, Engstrom-Ost J, Viitasalo M (2005) Turbidity decreases anti-predator behaviour in pike larvae, Esox Lucius. Environ Biol Fish 73(1):1-8

Leslie HA, Moester M, de Kreuk M, Vethaak AD (2012) Pilot study on emissions of microplastics from wastewater treatment plants. $\mathrm{H} 2 \mathrm{O}$ 14(15):45-47

Levy J, Gopalakrishnan C (2010) Promoting ecological sustainability and community resilience in the US Gulf Coast after the 2010 Deep Ocean horizon oil spill. J Nat Res Poll Res 2:297-315

Lin C, Tjeerdema RS (2008) Crude oil, oil, gasoline and petrol. In: Jorgensen SE, Fath BD (eds) Encyclopedia of ecology, Ecotoxicology, vol 1. Elsevier, Oxford, pp 797-805

Lorenz JJ (2014) A review of the effects of altered hydrology and salinity on vertebrate fauna and their habitats in northeastern Florida bay. Wetlands 34:189-200

Loska K, Wiechuła D (2003) Application of principal component analysis for the estimation of source of heavy metal contamination in surface sediments from the Rybnik reservoir. Chemosphere 51(8):723-733

Major DN, Wang H (2012) How public health impact is addressed: a retrospective view on three different oil spills. Toxicol Environ Chem 94:442-467

Malaj E, von der Ohe PC, Grote M, Kühne R, Mondy CP, Usseglio-Polatera P, Brack W, Schäfer RB (2014) Organic chemicals jeopardize the health of freshwater ecosystems on the continental scale. Proc Natl Acad Sci U S A 111:9549-9554 
Mancuso M (2013) Fish welfare in aquaculture-editorial. J Aquacult Res Develop 3:4-6

Mancuso M, Caruso G, Adone R, Genovese L, Crisafi E, Zaccone R (2013) Detection of Photobacterium damselae sub sp. piscida in sea waters by fluorescent antibody. J Appl Aquac 25:337-345

Margesin R, Schinnur F (1997) Efficiency of endogenous and inoculated cold-adapted soil microorganisms for biodegradation of diesel oil in alpine soils. Appl Environ Microbiol 63:2660-2664

Martinez-Cordova LR, Enriquez-Ocana F (2007) Study of the benthic fauna in a discharge lagoon of the shrimp faro with special emphasis on polychaeta. J Biol Sci 7:12-17

Mateo-Sagasta J, Burke J (2010) Agriculture and water quality interactions: a global overview. SOLAW background thematic report-TR08. Food and Agriculture Organization of the United Nations (FAO), Rome

Mateo-Sagasta J, Zadeh SM, Turral H, Burke J (2017) Water pollution from agriculture: a global review. Food and Agriculture Organization of the United Nations, Rome and the International Water Management Institute on behalf of the Water Land and Ecosystems Research Program, Colombo

Mehmood MA, Qadri H, Bhat RA, Rashid A, Ganie SA, Dar GH, Shafiq-ur-Rehman (2019) Heavy metal contamination in two commercial fish species of a trans-Himalayan freshwater ecosystem. Environ Monit Assess Environ 191:104. https://doi.org/10.1007/s10661-019-7245-2

Mendil D, Uluözlu ÖD (2007) Determination of trace metal levels in sediment and five fish species from lakes in Tokat, Turkey. Food Chem 101(2):739-745

Mirto S, Bianchelli S, Gambi C, Krzelj M, Pusceddu A, Scopa M (2009) Fish-farm impact on metazoan meiofauna in the Mediterranean Sea: analysis of regional vs. habital effects. Mar Environ Res 69:38-47

Momba MNB, Osode AN, Sibewu M (2006) The impact of inadequate wastewater treatment on the receiving water bodies-case study: Buffalo City and Nkokonbe Municipalities of the Eastern Cape Province. Water SA 32:5

Moore CJ, Lattin GL, Zellers AF (2005) A snapshot of land-based contributions of plastic and other trash to coastal waters and beaches of Southern California, working our way upstream. Algalita Marine Research Foundation, Long Beach, CA

Morris JG (1999) Harmful algal blooms: an emerging public health problem with possible links to human stress on the environment. Annu Rev Energy Environ 24:367-390

Morrison G, Fatoki OS, Persson L, Ekberg A (2001) Assessment of the impact of point source pollution from the Keiskammahoek sewage treatment plant on the Keiskamma river- $\mathrm{pH}$, electrical conductivity, oxygen demanding substance (COD) and nutrients. Water SA 27(4):475-480

Mushtaq N, Bhat RA, Dervash MA, Qadri H, Dar GH (2018) Biopesticides: the key component to remediate pesticide contamination in an ecosystem. In: Environmental contamination and remediation. Cambridge Scholars Publishing, Cambridge, pp 152-178

Naylor R, Hindar K, Fleming IA, Goldburg S, Williams S, Volpe J, Whoriskey F, Eagle J, Kelso D, Mangel M (2005) Fugative salmon: assessing the risks of escaped fish from net-pen aquaculture. Bioscience 55(5):427-437

NEST (1991) Nigeria's threatened environment: a national profile. Nigerian Environmental Study/ Action Teams, Ibadan, p 288, ISBN-13: 9789783120303

Norén F (2007) Small plastic particles in coastal Swedish waters. KIMO, Sweden

NORMAN (2016) List of emerging substances, Network of Reference Laboratories, Research Centres and related Organisations for Monitoring of Emerging Environmental Substances (NORMAN)

Oberdorff T, Pont D, Hugueny B, Porcher J (2002) Development and validation of a fish based index for the assessment of 'river health' in France. Fresh Water Biol 47(9):1720-1734

OECD (2012) Organisation for Economic Co-operation and Development. New and emerging water pollutants arising from agriculture, prepared by Alistair B.A. Boxall, Paris

Oehlmann J, Schulte-Oehlmann U, Kloas W, Jagnytsch O, Lutz I, Kusk KO, Wollenberger L, Santos EM, Paull GC, Van Look KJ, Tyler CR (2009) A critical analysis of the biological impacts of plasticizers on wildlife. Philos Trans R Soc Lond B Biol Sci 364:2047-2062 
Paerl HW (1988) Nuisance phytoplankton blooms in coastal, estuarine and inland waters. Limnol Oceanogr 33:823-847

Paerl HW, Huisman J (2009) Climate change: a catalyst for global expansion of harmful cyanobacterial blooms. Environ Microbiol Rep 1:27-37

Paerl HW, Paul VJ (2012) Climate change: links to global expansion of harmful cyanobacteria. Water Res 46:1349-1363

Paez-Osuna F (2001) The environmental impact of shrimp aquaculture: causes, effects and mitigating alternatives. Environ Manag 28(1):131-140

Paez-Osuna F (2005) Restos y perspectivas de la camaroniculturaen la zona costera. Revistalatinoamericana de Recursosnaturales 1:21-31

Perkins S (2015) Nearly every seabird may be eating plastic by 2050. Science. https://doi. org/10.1126/science.add1694

Perkol-Finkel S, Benayahu Y (2007) Differential recruitment of benthic communities on neighboring artificial and natural reefs. J Exp Mar Biol Ecol 340:25-39

Petruccelli BP, Goldenbaum M, Scott B, Lachiver R, Kanjarpane D, Elliott E, Francis M, McDiarmid MA, Deeter D (1999) Health effects of the 1991 Kuwait oil fires: a survey of US army troops. J Occup Environ Med 41(6):433-439

Porter KG (1977) The plant-animal interface in freshwater ecosystems. Am Sci 65:159-170

Purvis A (1999) Ten largest oil spills in history. Planet Watch Time Int 153:12

Rajitha K, Mukherjee CK, VinuChandran R (2007) Applications of remote sensing and GIS for sustainable management of shrimp culture in India. Aquacult Eng 36(1):1-17

Randolph RC, Hardy JT, Fowler SW, Price ARG, Pearson WH (1998) Toxicity and persistence of nearshore sediment contamination following the 1991 Gulf War. Environ Int 24:33-42

Rashid A, Bhat RA, Qadri H, Mehmood MA (2019) Environmental and socioeconomic factors induced blood lead in children: an investigation from Kashmir, India. Environ Monit Assess 191(2):76. https://doi.org/10.1007/s10661-019-7220-y

Rathore HS, Nollet LM (2016) Handbook of pesticides: methods of pesticide residues analysis. CRC Press, Boca Raton, FL

Rochman CM (2013) Plastics and priority pollutants: a multiple stressor in aquatic habitats. Environ Sci Technol 47:2439-2440

Roos N, Wahab MA, Chamnan C, Thilsted SH (2007) The role of fish in food-based strategies to combat vitamin A and mineral deficiencies in developing countries. J Nutr 137(4):1106-1109

SACEP (2014) South Asian Co-operative Environmental Programme, Nutrient loading and eutrophication of coastal waters of the South Asian Seas-a scoping study

Schindler DW (1974) Eutrophication and recovery in experimental lakes: implications for lake management. Science 174:897-899

Schindler DW (2006) Recent advances in the understanding and management of eutrophication. Limnol Oceanogr 51:356-363

Schneider O, Sereti V, Eding EH, Verreth AJ (2005) Analysis of nutrient flows in integrated intensive aquaculture systems. Aquac Eng 32(3-4):379-401

Schreinemachers P, Tipraqsa P (2012) Agricultural pesticides and land use intensification in high, middle and low income countries. Food Policy 37:616-626

Schwarzenbach RP, Egli T, Hofstetter TB, Von Gunten U, Wehrli B (2010) Global water pollution and human health. Annu Rev Environ Res 35:109-136

Shafir S, Rijn JV, Rinkevich B (2003) The use of coral nubbins in coral reef ecotoxicology testing. Biomol Eng 2:401-406

Shafir S, Rijn JV, Rinkevich B (2007) Short and long term toxicity of crude oil and oil dispersants to two representative coral species. Environ Sci Technol 41:5571-5574

Sharma YC (2012) A guide to the economic removal of metals from aqueous solutions. Wiley, Hoboken, NJ

Smith MD, Roheim CA, Crowder LB, Halpern BS, Turnipseed M, Anderson JL, Asche F, Bourillon L, Guttormsen AG, Khan A, Liguori LA, McNevin A, O'connor MI, Squires D, Tyedmers P, Brownstein C, Carden K, Klinger DH, Sagarin R, Selkoe KA (2010) Sustainability and global seafood. Science 327(5967):784-786 
Stickney RR, McVey JP (2002) Responsible marine aquaculture. New York, World Aquaculture Society

Sutherland WJ, Clout M, Cote IM, Daszak P, Depledge MH, Fellman L, Fleishman E, Garthwaite R, Gibbons DW, De Lurio J, Impey AJ, Lickorish F, Lindenmayer D, Madgwick J, Margerison C, Maynard T, Peck LS, Pretty J, Prior S, Redford KH, Scharlemann JPW, Spalding M, Watkinson AR (2010) A horizon scan of global conservation issues for 2010. Trends Ecol Evol 25:1-7

Teuten EL, Saquing JM, Knappe DR, Barlaz MA, Jonsson S, Bjorn A, Rowland SJ, Thompson RC, Galloway TS, Yamashita R, Ochi D, Watanuki Y, Moore C, Viet PH, Tana TS, Prudente M, Boonyatumanond R, Zakaria MP, Akkhavong K, Ogata Y, Hirai H, Iwasa S, Mizukawa K, Hagino Y, Imamura A, Saha M, Takada H (2009) Transport and release of chemicals from plastics to the environment and to wildlife. Philos Trans R Soc Lond B Biol Sci 364:2027-2045

Thebo AL, Drechsel P, Lambin EF, Nelson KL (2017) A global, spatially explicit assessment of irrigated croplands influenced by urban wastewater flows. Environ Res Lett 12:074008

Thompson RC (2015) Mircoplastics in the marine environment: sources, consequences and solutions. In: Bergmann M, Gutow L, Klages M (eds) Marine anthropogenic litter. Springer, Heidelberg, pp 185-200

Tidwell JH, Allan GL (2001) Fish as food: aquaculture's contribution: ecological and economic impacts and contributions of fish farming and capture fisheries. EMBO Rep 2(11):958-963

Tidwell LG, Allan SE, O'Connell SG, Hobbie KA, Smith BW, Anderson KA (2015) Polycyclic aromatic hydrocarbon $(\mathrm{PAH})$ and oxygenated $\mathrm{PAH}(\mathrm{OPAH})$ air-water exchange during the deepwater horizon oil spill. Environ Sci Technol 49:141-149

Tillmanns AR, Wilson AE, Pick FR, Sarnelle O (2008) Meta-analysis of cyanobacterial effects on zooplankton population growth rate: species-specific responses. Fund Appl Limnol 171:285-295

Tukura BW, Kagbu JA, Gimba CE (2009) Effects of pH and seasonal variations on dissolved and suspended heavy metals in dam surface water. Chem Class J 6:27-30

Turner AM, Chislock MF (2010) Blinded by the stink: nutrient enrichment impairs the perception of predation risk by freshwater snails. Ecol Appl 20:2089-2095

UNEP (2006) Water quality for ecosystem and human health. United Nations Environment Programme Global Environment Monitoring System (GEMS)/Water Programme

UNEP (2011) UNEP yearbook: emerging issues in our global environment. UNEP Division of Early Warning and Assessment, Nairobi

UNEP (2016) A snapshot of the world's water quality: towards a global assessment. United Nations Environment Programme, Nairobi

USEPA (2016) Water quality assessment and TMDL information. United States Environmental Protection Agency, Washington, DC

Van Cauwenberghe L, Vanreusel A, Mees J, Janssen CR (2013) Microplastic pollution in deep- sea sediments. Environ Pollut 182:495-499

Vargas-Gonzalez HH, Arreola-Lizarraga JA, Mendoza-Salgado RA, Mendez-Rodriguez LC, Lechuga-Deveze CH, Padilla-Arrendondo GP, Cordoba-Matson M (2014) Effect of sewage discharge on trophic state and water quality in a coastal ecosystem of the gulf of California. Sci World J 2014:618054

Watt I (1994) An outline for the development of a contingency plan to combat oil pollution in the Gulf sanctuary. In: Feltamp E, Krupp F (eds) Establishment of a marine habitat and wildlife sanctuary for the Gulf region. Final report for phase II. CEC/NCWCD, Jubail and Frankfurt, pp 38-80

WHO (2006) Guidelines for the safe use of wastewater. Excreta, and greywater. World Health Organization, Geneva

WHO (2012) Animal waste, water quality and human health. World Health Organization, Geneva

Wilson AE, Sarnelle O, Tillmanns AR (2006) Effects of cyanobacterial toxicity and morphology on the population growth of freshwater zooplankton: meta-analyses of laboratory experiments. Limnol Oceanogr 51:1915-1924 
WRI (2008) World Resources Institute, Eutrophication and hypoxia in coastal areas: a global assessment of the state of knowledge. WRI Policy Note, Washington, DC

Wright SL, Thompson RC, Galloway TS (2013) The physical impacts of microplastics on marine organisms: a review. Environ Pollut 178:483-492

Wu SD, Zhao HF (2006) The analytical methods in the monitoring of water and wastewater. China Environmental Science Press, Beijing

WWAP (2015) United Nations world water assessment programme, the United Nations world water development report 2015: water for a sustainable world. United Nations Educational, Scientific and Cultural Organization, Paris

WWAP (2017) United Nations world water assessment programme, the United Nations world water development report 2017: wastewater, the untapped resource. United Nations Educational, Scientific and Cultural Organization, Paris

Xanthos D, Walker TR (2017) International policies to reduce plastic marine pollution from singleuse plastics (plastic bags and microbeads): a review. Mar Pollut Bull 118(1-2):17-26

Xiong S, Long H, Tang G, Wan J, Li H (2015) The management in response to marine oil spill from ships in China: a systematic review. Mar Pollut Bull 96(1-2):7-17

Xu JL, Yang JR (1996) Heavy metals in terrestrial ecosystem. China Environmental Science Press, Beijing

Zarfl C, Matthies M (2010) Are marine plastic particles transport vectors for organic pollutants to the Arctic? Mar Pollut Bull 60:1810-1814

Zhou Q, Zhang J, Fu J, Shi J, Jiang G (2008) Biomonitoring: an appealing tool for assessment of metal pollution in the aquatic ecosystem. Anal Chim Acta 606(2):135-150

Zubris KA, Richards BK (2005) Synthetic fibers as an indicator of land application of sludge. Environ Pollut 138:201-211 